\title{
Childhood Idiopathic Thrombocytopenic Purpura: Oral Manifes- tations and Dental Care
}

\section{Rafaela Brito Vasconcelos ${ }^{1 *}$, Gabriela Brito Vasconcelos ${ }^{2}$, Michele Gomes do Nascimento ${ }^{3}$ and Viviane Colares $^{4}$}

\begin{abstract}
${ }^{1}$ Student, Specialization in Pediatric Dentistry, Center for Post-Graduation in Dentistry, Brazil
${ }^{2}$ Student, Specialization in Periodontology, Brazilian Association of Dentistry, Brazil

${ }^{3}$ Doctoral Student in Pediatric Dentistry, Faculty of Dentistry, University of Pernambuco, Brazil

${ }^{4}$ Associate Professor of Pediatric Dentistry, Faculty of Dentistry, University of Pernambuco and Federal University of Pernambuco, Brazil
\end{abstract}

*Corresponding author: Rafaela Brito Vasconcelos, Student, Specialization in Pediatric Dentistry, Centerfor Post-Graduation in Dentistry, Rua Demócrito de Souza Filho, 350, Madalena, Recife-PE, CEP: 50610120, Brazil, Tel: 81-988362803

\begin{abstract}
Oral manifestations may be the first clinical signs of idiopathic thrombocytopenic purpura (ITP) diagnosed by a pediatric dentist. The aim of the present study was to describe oral manifestations and dental care for patients with ITP. A narrative review of the literature was performed, involving a search in the MEDLINE (PubMED) electronic database for relevant articles published in English using the following keywords: "Purpura, Thrombocytopenic, Idiopathic", "Hematologic diseases" and "Dental care". No restrictions were imposed with regard to the year of publication. The inclusion criteria were studies that addressed oral manifestations and dental management in patients with ITP. This condition is considered one of the most common blood disorders in children. Manifestations such as spontaneous or trauma-induced gingival bleeding, petechiae, hematomas, purpura and ecchymosis are reported in regions of the vestibular mucosa, lateral edges of the tongue and the junction between the hard and soft palate as well as other sites of the oral mucosa. Oral management depends on the status of the disease, which is reflected in the platelet count. Moreover, the inclusion of a hematologist on the treatment team is fundamental. In the occurrence of these manifestations, a detailed patient history is the key to successful oral treatment for these patients to avoid inflammation, gingival bleeding and infection.
\end{abstract}

\section{Keywords}

Purpura, Thrombocytopenic, Idiopathic, Hematologic diseases, Dental care

\section{Abbreviations \\ ITP: Idiopathic Thrombocytopenic Purpura}

\section{Introduction}

Thrombocytopenia is a blood disorder characterized by an accentuated reduction in platelets. This reduction in number and function may stem from different mechanisms, such as autoimmune destruction, spleen sequestration, bone marrow failure, infiltration by tumor cells and an adverse drug reaction [1].

Idiopathic thrombocytopenic purpura (ITP) is one of the most common causes of symptomatic thrombocytopenia in children, [2,3] with the annual incidence of ITP is estimated to be between 1 and 6.4 cases per 100,000 children $[2,4]$. The most common clinical symptoms are hematoma, petichiae, bleeding of the mucous membranes and other hemorrhagic manifestations of thrombycytopenia [5-7].

Oral manifestations are often among the first findings of thrombocytopenia, such as gingival bleeding stemming from trauma in the oral cavity $[1,8]$. Therapy for patients with ITP depends on the conditions found as well as the relationship to dental treatment. The clinical approach of the pediatric dentist should be based on prior knowledge of the evolution of the disease in the patient [9].

The aim of the present study was to describe oral manifestations and care (pediatric dentistry) for patients with idiopathic thrombocytopenic purpura.

Citation: Vasconcelos RB, Vasconcelos GB, do Nascimento MG, de Andrade Amorim VCS (2018) Childhood Idiopathic Thrombocytopenic Purpura: Oral Manifestations and Dental Care. Int J Oral Dent Health 4:067. doi.org/10.23937/2469-5734/1510067

Accepted: October 30, 2018: Published: November 01, 2018

Copyright: (C) 2018 Vasconcelos RB, et al. This is an open-access article distributed under the terms of the Creative Commons Attribution License, which permits unrestricted use, distribution, and reproduction in any medium, provided the original author and source are credited. 


\section{Materials and Methods}

A narrative review of the literature was performed, involving a search in the MEDLINE (PubMED) electronic database for relevant articles published in English using the following keywords: "Purpura, Thrombocytopenic, Idiopathic", "Hematologic diseases" and "Dental care". No restrictions were imposed with regard to the year of publication. The inclusion criteria were studies that addressed oral manifestations and dental management in patients with ITP.

\section{Literature Review}

\section{Concept and diagnosis}

ITP is an acquired disorder characterized by mild to severe thrombocytopenia in the absence of any other abnormality. The two main mechanisms involved in the pathogenesis of this condition are an increase in the destruction of or reduction in the production of platelets [8]. Platelet reduction can occur in cases of bone marrow failure syndromes, such as aplastic anemia or myelodysplastic syndrome, and chemotherapy-induced or drug-induced thrombocytopenia [8].

According to different authors [9-13], the diagnosis of ITP is performed by exclusion, as the differential diagnosis includes other conditions with distinct etiologies that can lead to the general symptoms of thrombocytopenic purpura, such as those mentioned above and hereditary thrombocytopenia (Bernard-Soulier syndrome and Aldrich-Schlonlein syndrome), vitamin C deficiency, viral infections (HIV, infectious mononucleosis), autoimmune disorders (systemic lupus erythematosus), acute leukemia and Hodgkin's lymphoma.

\section{Forms of presentation}

ITP clinical signs include petechiae, ecchymoses, haematomas, epistaxis, haematuria, mucocutaneous bleeding, and occasionally, haemorrhage into tissues. Complications are rare. In general, splenomegaly is not common, being in acute form IPT, spleen only palpable in $10 \%$ of the cases [13].

The disease has two forms: Acute and chronic. The chronic form is known as childhood ITP, which can affect children of both sexes under ten years of age as well as young adults [14-16]. It has been associated with a history of viral infection two to 21 days prior to the first clinical signs and onset of ITP [9,15-19]. The acute form has been associated with infection by Epstein-Barr virus, varicella-zoster virus, after vaccinations for rubella, mumps and measles as well as other infections of different etiologies $[13,20,21]$. This condition is usually self-limiting, with remission occurring within several weeks or months [22], more specifically within six months, according to Sugiura, et al. [12].

For the chronic form, which is characteristically seen in adults, there is no consensus in the literature regard- ing its duration. Some authors define it as persisting for more than six months $[14,23]$. However, the classification proposed in 2009 defines chronic ITP as the occurrence of the disease for more than 12 months [24]. The symptomatic manifestations of this form are generally mild $[13,22]$.

\section{Oral manifestations}

The oral cavity merits special attention as a predisposing factor for diverse systemic disorders given its particular anatomic and physiologic aspects [25]. Oral manifestations of blood diseases may be the first clinical signs found by a dentist, serving as a guide for a detailed patient history [26].

Spontaneous bleeding or bleeding induced by trauma, such as during brushing or the use of dental floss, is often the first sign of thrombocytopenia $[1,8,23]$. Signs such as petechiae, hematoma, purpura and ecchymosis are reported in the region of the vestibular mucosa, lateral edges of the tongue and the junction between the hard and soft palate $[8,13,23]$, which are prone to trauma. Other signs include multiple hemorrhagic blisters on the sublingual mucous membrane, floor of the mouth or lateral surface of the tongue, according to Byatnal, et al. [27].

With regards to the tissue reactions, there are few reports in the literature of the appearance of gingival hyperplasia. In a study evaluating forms of treatment for refractory childhood ITP, it was reported that the use of Ciclosporin A caused the gingival growth as an adverse reaction in 10 patients within a control group of 21 patients [28]. These were results identical with those already reported in China [29].

The frequent finding of gingival bleeding in routine clinical dentistry [12] underscores to the need for a detailed patient history to determine the diagnosis with the inclusion or exclusion of different causal factors, such as periodontal disease, trauma, anticoagulant therapy, bacterial infection, leukemia and blood disorders [27] such as ITP. Blood disorders, in particular, exhibit characteristic abnormal bleeding with a sudden onset that is difficult to control [9].

\section{Dental management}

Dental management depends on the platelet count [8], which should be higher than $50,000 / \mathrm{mm}^{3}$ before any treatment should be performed. Moreover, treatment should only be performed with the knowledge of the patient's hematologist [30]. There is no consensus in the literature regarding surgical procedures. According to some authors, a platelet count lower than 50,000 $\mathrm{mm}^{3}$ requires transfusion or corticosteroid therapy prior to surgery [31,32]. However, the American Hematology Society states that corticosteroids or intravenous infusion are only necessary when the platelet count is lower than 30,000/ $\mathrm{LL}$ [33]. For minor and major surgery, 
the margin of safety is $\geq 50,000$ and $\geq 80,000$ cells $/ \mu \mathrm{L}$, respectively [34].

First-intention healing of surgical wounds can be achieved with hemostatic measures, such as manual compression with gauze and the local injection of a vasoconstrictor [13]. The filling of the alveolus with absorbable gelatin sponges, microfibrillar collagen [32] or oxidized regenerated cellulose is also useful in cases of bleeding. Electrical cauterization or the application of bone wax are other options for controlling hemorrhage [13]. For the management of trans-operative pain, infiltrative and intra-ligament anesthetic techniques are preferable for patient with ITP [35]. Inferior alveolar nerve block is contraindicated due to the greater chance of the formation of a hematoma [36].

Nonsurgical procedures as gingival probing, scaling and root planning may be performed without risk gingival bleeding, as long as it is carefully. Fine curettes and scalers should be used, or ultrasonic instrumentation, due less tissue trauma [8].

Regarding medication therapy employed in such patients, antiplatelet aggregating drugs and non-steroidal anti-inflammatory drugs should be avoided $[8,37]$. The use of acetaminophen-based drugs or selective COX-2 inhibitors is preferable [8]. However, the drug line of choice for these patients is a corticosteroid, taking due care to avoid adrenal failure [8].

\section{Prevention}

A possible lack of oral hygiene may be noted among individuals with a coagulopathy due to the fear of exacerbated bleeding following brushing and the use of dental floss [37]. In the long term, this lack of hygiene can lead to periodontal problems and caries [37]. Therefore, adequate plaque control is fundamental to the prevention of inflammation, gingival bleeding and infection in these patients $[13,14,38]$.

An individualized prevention program should be implemented based on the patient's age and the risk of caries $[13,14]$. The use of a fluoride toothpaste and dietary counseling should be instituted. Depending on the risk of caries and the optimum quantity of fluoride in the water supply, daily mouth rinsing with fluoride and systemic fluoride supplements may be recommended. Moreover, dental office procedures, such as the topical application of fluoride or chlorhexidine as well as the sealing of pits and fissures, are preventive measures that can be performed [13].

\section{Conclusion}

Oral manifestations, such as spontaneous bleeding or bleeding induced by trauma, may be the first clinical signs of idiopathic thrombocytopenic purpura (ITP) diagnosed by a pediatric dentist. Other signs of this disease include petechiae, hematomas, purpura and ecchymosis, which are reported in diverse sites of the oral mucosa. Oral management depends on the status of the disease, which is reflected in the platelet count. Moreover, the inclusion of a hematologist on the treatment team is fundamental. Prevention is the key to successful oral treatment for these patients to avoid inflammation, gingival bleeding and infection.

\section{Acknowledgments}

The authors acknowledge the studies addressing this peculiar disorder, which requires special care, and the contribution of the scientific community, which provided the data found in the literature that guided this review. Conflict of interest: The authors declare no conflicts of interest. Funding: This study did not have any funding sources.

\section{References}

1. Amit Byatnal, Neha Mahajan, Shrinivas Koppal, Ravikiran A, Thriveni R, et al. (2013) Unusual yet isolated oral manifestations of persistent thrombocytopenia-a rare case report. Braz J Oral Sci 12: 233-236.

2. D'Orazio JA, Neely J, Farhoudi N (2013) ITP in children: Pathophysiology and current treatment approaches. J Pediatr Hematol Oncol 35: 1-13.

3. Alam MM (2014) Idiopathic thrombocytopenic purpura in children: A 10 years' experience at tertiary care hospital. J Pak Med Assoc 64: 1358-1362.

4. Terrell DR, Beebe LA, Vesely SK, Neas BR, Segal JB, et al. (2010) The incidence of immune thrombocytopenic purpura in children and adults: A critical review of published reports. Am J Hematol 85: 174.

5. George JN, Rizvi MA (2001) Thrombocytopenia. In: Beutler E, Lichtman MA, Coller BS, Kipps TJ, Seligsohn U, Williams Hematology. (6 $6^{\text {th }}$ edn), McGraw-Hill Medical Publishing Division, New York, USA, 1495.

6. Bolton-Maggs PH, Moon I (1997) Assessment of UK practice for management of acute childhood idiopathic thrombocytopenic purpura against published guidelines. Lancet 350: 620-623.

7. Schlosser BJ, Pirigyi M, Mirowski GW (2011) Oral manifestations of hematologic and nutritional diseases. Otolaryngol Clin N Am 44: 183-203.

8. Neha Bansal, Manika Jindal, Narinder Dev Gupta, Pradeep Shukla (2017) Clinical guidelines for periodontal management of idiopathic thrombocytopenic purpura: Current considerations. IJOHS 7: 30-34.

9. Hunter ML, Hunter B, Lesser L (1997) Acute idiopathic thrombocytopenic purpura in childhood: Report of a case presenting in general dental practice. Br Dent J 183: 27-29.

10. Ozsoylu S, Karabent A, Irken G, Tuncer M (1991) Antiplatelet antibodies in childhood idiopathic thrombocytopenic purpura. Am J Hematol 36: 82-85.

11. Cines DB, Bussel JB (2005) How I treat idiopathic thrombocytopenic purpura (ITP). Blood 106: 2244-2251.

12. Tsutomu S, Kazuhiko Y, Kazuhiro M, Satoshi H, Yumiko M, et al. (2018) Immune Thrombocytopenic purpura detected with oral hemorrhage: A case report. J Dent 19: 159-163.

13. Vaisman B, Medina AC, Ramirez G (2004) Dental treatment for children with chronic idiopathic thrombocytopaenic purpura: A report of two cases. Int J Paediatr Dent 14: 355-362. 
14. Viviane Ferreira R, Stella Maria Coda Pinto Alves Campos V, Ana Lidia C, Renata de Oliveira G (2015) Dental considerations on the management of idiopathic thrombocytopenic purpura in children: Case report. Rev Gauch Odontol 63: $472-476$.

15. James WD, Guiry CC, Grote WR (1984) Acute idiopathic thrombocytopenic purpura. Oral Surgery 57: 149-151.

16. Lowe EJ, Buchanan GR (2002) Idiopathic thrombocytopenic purpura diagnosed during the second decade of life. $J$ Pediatr 141: 253-258.

17. Ganong WF (1977) Fluidos circulantes do organismo. In: Ganong WF, Fisiologia médica. ( $3^{\text {rd }}$ edn), Atheneu, Sao Paulo, Brazil, 385-399.

18. McClure PD (1975) Idiopathic thrombocytopenic purpura in children: diagnosis and management. Pediatrics 55: 68.

19. McWilliams NB, Maurer HM (1979) Acute idiopathic thrombocytopenic purpura in children. Am J Hematol 7: 87-96.

20. Jonville-Béra AP, Autret E, Galy-Eyraud C, Hessel L (1996) Thrombocytopenic purpura after measles, mumps and rubella vaccination: A retrospective survey of French regional pharmaco vigilance centres and Pasteur-mérieux serums and vaccines. Pediatric Infectious Diseases Journal 15: 44-48.

21. Nieminen $U$, Peltola $H$, Syrjälä $M T$, Mäkipernaa $A$, Kekomäki R (1993) Acute thrombocytopenic purpura following measles, mumps and rubella vaccination. A report on 23 patients. Acta Paediatr 82: 267-270.

22. Martins G, Rozas FG, Ribas MO, Martins WD (2010) Idiopathic thrombocytopenic purpura and oral surgery: Case report rev. Clín Pesq Odontol 6: 87-93.

23. Sujata Satoskar, Tajindra Singh Saluja, Sapna Raut Dessai, Aarthi Shenoy (2016) Oral manifestations of immune thrombocytopenic purpura: A diagnosis of exclusion. IOSRJDMS 15: 65-67.

24. Rodeghiero F, Stasi R, Gernsheimer T, Michel M, Provan $D$, et al. (2009) Standardization of terminology, definitions and outcome criteria in immune thrombocytopenic purpura of adults and children: Report from an international working group. Blood 113: 2386-2393.

25. Owais Z, Dane J, Cumming CG (2003) Unprovoked periodontal hemorrhage, life-threatening anemia and idiopathic thrombocytopenia purpura: An unusual case report. Spec Care Dentist 23: 58-62.

26. Adeyemo TA, Adeyemo WL, Adediran A, Akinbami AJ,
Akanmu AS (2011) Orofacial manifestations of hematological disorders: Anemia and hemostatic disorders. Indian J Dent Res 22: 454-461.

27. Byatnal A, Mahajan N, Koppal S, Ravikiran A, Thriveni R, et al. (2013) Unusual yet isolated oral manifestations of persistent thrombocytopenia: A rare case report. Braz J Oral Sci 12: 233-236

28. Liu QC, Wu WH, Wu DY, Feng XW, Ma YH, et al. (2008) Clinical observation on the treatment of childhood refractory idiopathic thrombocytopenic purpura with dihuang zhixue capsule. Chin J Integr Med 14: 132-136.

29. Yang N, Cai J (2002) Clinical observation of cyclosporin a in the treatment of refractory chronic idiopathic thrombocytopenic purpura. J Pract Diagn Ther 16: 286-287.

30. Akin L, Herford AS, Cicciù M (2011) Oral presentation of disseminated histoplasmosis: A case report and literature review. J Oral Maxillofac Surg 69: 535-541.

31. Bal MV, Koyuncuoglu CZ, Saygun I (2014) Immune thrombocytopenic purpura presenting as unprovoked gingival hemorrhage: A case report. Open Dent J 8: 164-167.

32. Little JW, Falace DA (1993) Dental management of the medically compromised patient. ( $4^{\text {th }}$ edn), MO: Mosby, St Louis, 423-438.

33. Wagner WR, Pachence JM, Ristic J, Johnson PC (1996) Comparative in vitro analysis of topical hemostatic agents. J Surg Res 66: 100-108.

34. Provan D, Stasi R, Newland AC, Blanchette VS, BoltonMaggs $P$, et al. (2010) International consensus report on the investigation and management of primary immune thrombocytopenia. Blood 115: 168-186.

35. British committee for standards in haematology general haematology task force (2003) Guidelines for the investigation and management of idiopathic thrombocytopenic purpura in adults, children and in pregnancy. $\mathrm{Br} \mathrm{J}$ Haematol 120: 574-596.

36. Patton LL (2003) Bleeding and clotting disorders. In: Greenberg MG, Burket's oral medicine: Diagnosis and treatment. (10 ${ }^{\text {th }}$ edn), ON: BC Decker; Hamilton, 454-477.

37. Gupta A, Epstein JB, Cabay RJ (2007) Bleeding disorders of importance in dental care and related patient management. J Can Dent Assoc 73: 77-83.

38. Guzeldemir E (2009) The role of oral hygiene in a patient with idiopathic thrombocytopenic purpura. Int J Dent Hyg 7: $289-293$ 